\title{
NETWORK THROUGH CENTURIES: FROM THE BYZANTINE ERA TO PRESENT DAYS
}

\author{
E. Fioretto ${ }^{1}$ \\ ${ }^{1}$ Politecnico di Milano, Dept. ABC, Via Ponzio 31, 20133 Milano - elena.fioretto@ polimi.it
}

KEY WORDS: Archaeological sites, Network, Cultural Heritage, Preservation, Valorisation, Byzantine Empire

\begin{abstract}
:
Over the centuries, the Roman Empire enlarge and restrict its borders, as a consequence of many factors, like different emperor's policies, wars and conquests.

In a general view, we can identify them and we can consider the Danubian Limes as one of the most important one.

This Limes was mostly characterized by the fact that it was corresponded with the path of the Danube river, from Germany till the Black Sea.

Those lands, through centuries, were always threaten by the risk of barbarians' incursions and this is the reason why the Danubian Limes had always been considered as a fragile border.

During the sixth century, in the midst Byzantine Era, Justinian the I was the first emperor able to consider the problem of the military protection not even "site by site". He felt the need of an (absolutely modern) idea of considering the limes as a network of sites, who need each other to guarantee a strong and efficient result.

Speaking about the architectonical choices, the system of military camps and fortress starts to change its identity, becoming cities with specific relations.

Focusing on the case study of Serbia, the aim of the work is to map the specific location of each archaeological site, trying to use this network as an index of places. The research would like to highlight the important value of those sites as Cultural Heritage, considering the necessity of their preservation and valorization as historical evidence in a new European and common scenario.
\end{abstract}

\section{INTRODUCTION}

The work that is going to be presented is part of an ongoing research, that starts from the idea to investigate the potentialities of an Intercultural Dialogue ${ }^{1}$ between researchers in the field of architectural preservation, through the study for the conservation and valorization of Cultural Heritage ${ }^{2}$.

The case study that this research would like to investigate is the Balkan region, with a special attention to Serbia.

${ }^{1}$ the definition of Intercultural Dialogue, as declared in 2001 by the Universal Declaration on Cultural Diversity of UNESCO:

"In our increasingly diverse societies, it is essential to ensure harmonious interaction among people and groups with plural, varied and dynamic cultural identities as well as their willingness to live together. Policies for the inclusion and participation of all citizens are guarantees of social cohesion, the vitality of civil society and peace. Thus defined, cultural pluralism gives policy expression to the reality of cultural diversity. Indissociable from a democratic framework, cultural pluralism is conducive to cultural exchange and to the flourishing of creative capacities that sustain public life" (Article 2, "From cultural diversity to cultural pluralism").

${ }^{2}$ Cultural Heritage is an essential instrument for the Intercultural Dialogue, as defined, in 2015, by the Namur Declaration: (point 2 of the Declaration) "Cultural Heritage is a key component of the European identity; it is of general public interest and its transmission to future generations is a shared responsibility; it is a unique resource, fragile, non-renewable and non-relocatable, contributing to the attractiveness and the development of Europe and, crucially, to the creation of a more peaceful, just and cohesive society".
It's almost impossible to summarize the long, huge and complex process of historical events that let the Balkan region, through centuries, became a land of migration's activity, as outcomes of a spontaneous or forced transfers of people.

The result is an ethnic mix, especially in the border areas of this region.

Groups of people with different origins, during the years paved the way for who's Hösch ${ }^{3}$ consider as a "Balcanic mix" ("Miscuglio balcanico", in the source red by the author).

Taking into consideration the recent history of these countries, we have to note that with the Russian Revolution, so starting from 1917, and especially with the Cold War, a wall has been created between the Eastern and the Western part of Europe.

This kind of censorship lasts for many decades, still recent times, and those countries were projected, in a really brief period, in a word that was grown with different habits and rules. Nowadays, a lot of countries are fully involved in a European strategy to enlarge the boundaries of Europe, including the Balkan region.

It is a strategical and really interesting moment of the history, that can become an important occasion to implement our knowledge.

The relation between Italy and Serbia, that is the most important case study of this research, is rooted on the common ancient background, represented by the common belonging to the Roman Empire.

And, especially, we are speaking about that Roman Empire that nowadays we used to call "Byzantine Empire", that, chronologically, can be identified between the 395 a.C., after the death of the roman emperor Teodosio I, and the 1453, with the Fall of Constantinople to the Ottoman Empire.

From the geographical point of view, subjects of our interest are the boundaries of the Byzantine empire, that, over the centuries,

\footnotetext{
${ }^{3} \mathrm{HÖSCH} 2006$
} 
had been enlarged and restricted as a consequence of many factors, like different emperor's policies, wars and conquests. Generally speaking, they could be differenced by two main characteristics: natural and artificial boundaries.

Under the artificial category we could identify, for instance, the Vallo di Adriano, or Vallo di Antonino, built from new thanks to the work of man and soldiers.

Under the natural category it is possible to identify each situation where the limes (boundary, in his latin and original name) corresponds to a natural geographical element. It is possible to generally count them in three main situations, it means where the boundary is represented by:

Mountains, as the case of Carpazi in the roman Province of Dacia;

Desert, as in Egypt

- Rivers, as in the cases of the rivers Rhine, Euphrates and Danube.

In any case, if from one side the idea itself of boundary entails the meaning of the last part of something, in our case the lands of an Empire, from another side it entails the complex system of relations between what belong to one and the other side of this line.

The considered case study of the Danubian Limes seems to be interesting also for this aspect: it is that boundary of the Empire that divide the roman land from the "barbarian" one: those lands, through centuries, were always threaten by the risk of barbarians' incursions and this is the reason why the Danubian Limes had always been considered as a fragile border.

Nowadays the Danube river flows through ten countries, becoming the boundary between some of them, connecting Germany to the Black Sea.

During the roman era the difficulties to defend a so huge portion of land implied the constant modifications of the boundary of the Empire on this side, as a consequence of so many wars and conquest by barbarians' populations.

The peak has been reached during the fifth century, with the big phenomenon of the Barbarian Invasions, represented mostly, along the Danube river, by the Huns. This historical phase implied a big loss of architectural manufacts along the Limes, destroyed during the wars for the conquest of new lands by Huns.

But in the sixth century, and we are reaching the core of the research, thanks to the policy of the emperor Justinian I, the Danubian Limes starts to take on a new role.

Justinian the I was able to understand the need of a (modern) necessity to create a network of sites, to reach a situation of balance on the limes defense policy.

Balance in terms of a new safety for the boundary and balance in terms of a broad-minded approach about the strategic set-up of the defense system.

As well as we can understand from the words of Procopio di Cesarea $^{4}$, through the studies of Enrico Zanini, "in the new project for the Danubian Limes, Justinian I didn't limit himself to restore what was already built, but he carried out a real plan of restorations, re-buildings and new constructions, sometimes including also some removals. It's seemed that, according also the words of Procopio, he forced himself to homogenize the dimensions of the defense system: enlarging little fortresses,

\footnotetext{
${ }^{4}$ The research will adopt the 560 a.C. as a "terminus post-quem", because some historians make it coincide with the first publication of the "De Aedificiis" opera by Procopio da Cesarea. This document is mostly important for this research, because it can be considered as the first systematic census of architectonical proprieties of the Eastern Roman Empire.
}

reducing too big ones and building from new fortress wherever he felt the need of them".

\section{A NETWORK OF SITES: THE DANUBIAN LIMES}

In the Giulio-Claudia Era (27-68 a.C.) the defense system of the Danubian Limes was represented by simple tent's camps, defended by palisades.

Approximately on the first half of the second century the design of castrum starts to reach its characteristic pattern, divided in four parts, by two orthogonal main paths. The Limes, at that time, is an offensive structure. Fortresses played the role of logistical support for troops, engaged in wars of conquest of the Dacia.

During the third century we can note a new change of perspective about the internal organization of the castrum plan. New buildings appear in the plan of the settlement, probably with the function of warehouses. The result is a modification of the original quadripartite military facility. It is possible to assume this change also with a theoretical interpretation: the limes starts to play a new role, now defensive rather than offensive.

The defensive line is moving towards a dual process of evolution. On one hand, the limes is enhanced to build a barrier against the incursions of barbarians ${ }^{6}$.

On the other hand, the limes begins to get involved in a new way, starting new relationships with the territory that it must defend and administer. In that period the new and urgent problem of the Illyricum, considered as a border's region, arose. The traditional Roman concept of the defense system, which considered the Limes as a militarized band that can defend and isolate the empire, began to enter into crisis; but, at the same time it was also considered as the finis, the political, administrative, economic and, especially, cultural and religious frontier, between the Roman and not Roman.

We can consider this period as the beginning of a limit differentiation process; it can be introduced a new distinction between political and administrative limit and cultural limit, between the frontier and the border, but it will take on full significance only in the Justinian I era ${ }^{7}$.

In the Justinian I program of Renovatio Imperii we notice an extraordinary relevance regarding the recapture of the Danube banks.

The re-definition of the defensive and administrative boundaries is indeed the last attempt to stave off the pressure of Slavs. It felt the need to maintain a political and administrative control over a complex region: the complexity of its layout did not relieve it from play a central role in the general economy of the Empire.

From an architectural point of view, it should be noted that the internal organization of castra detects a gradual shift: from a purely military organization, articulated on quadripartite scheme, we can see a growing rise of foreign organism's encampment. Justinian adopts a standardization policy in his immense construction effort along the Danubio river, expanding

\footnotetext{
${ }^{5}$ This part has been translated by the author. Here the original version, in Italian: "Nell'intervenire sul limes danubiano, Giustiniano non si limita a restaurare l'esistente, ma attua un piano preciso ed articolato di restauri, di riedificazioni, di nuove costruzioni e, in diversi casi, di eliminazioni. Sembra di cogliere, anche sulla base delle indicazioni di Procopio di Cesarea, uno sforzo di omogeneizzazione delle dimensioni delle fortezze: si ampliano i forti più piccoli, si riducono le strutture troppo grandi ed onerose per la difesa e si costruiscono ex novo alcuni forti laddove se ne avverte la necessità". [ZANINI, 1987]

${ }^{6}$ TREADGOLD 2009

7 ZANINI 1986
} 
the smallest castra, resizing the widest ones, funding new ones. Procopio told about the characteristics of these castra, referring to a description of something like cities.

"As one goes on from Viminacium there chance to be three strongholds on the bank of the Ister, Pinci and Cupi and Novae. These were formerly both single in construction and when named were single towers. But now the Emperor Justinian has greatly increased the number of the houses and enlarged the defences at these places, and thereby has properly given them the rank of cities" $"$.

So, these are new fortified centers, but, now, surrounded by villages inhabited by civilians 9 .

What we must notice, therefore, is that the limes lost, gradually, its purely strategic-military role; the area is still under the jurisdiction of one dux, but, in fact, it becomes an area populated by citizens, who start to have business relationship, cultivate and breed animals.

If we would like to give a brief chronological view, we can divide the limes' role in these three parts:

1_ the limes was born as offensive structure,

2 the limes becomes a defensive structure

3_the limes plays the role of "dam", as a protection band in a context where it was clear that this area became, mostly, a contact and exchange zone, between different people and cultures.

This research is trying to explore and collect archaeological data to let us have a new and clear idea of the arrangement of the Danubian Limes under the reign of Justinian I.

It should be noticed that, during the 1960s and 1980s two dams were built along the Danube Limes. Unfortunately, these decisions implied that so many archaeological sites were sunk by the waters of the river.

The results of the excavations carried out due to the construction of the dams were published mostly in periodicals. Probably the most important publication about these archaeological areas is "Starinar", the official periodical of the Institute of Archaeology in Belgrade, especially the volumes XXXIII-XXXIV.

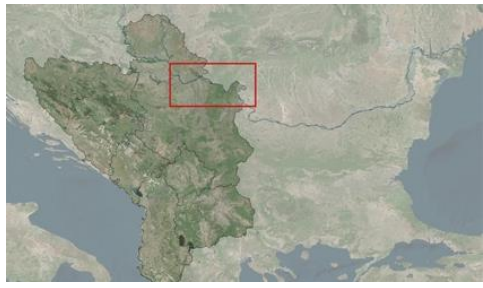

Figure 1 . General view of the analyzed area

1 - Singidunum - Belgrade

2 - Viminacium

3 - Lederata - Ram

4 - Castrum Novae - Cezava

5 - Saldum

6 - Ad Scrofulos - Bosman

7 - Smorna - Boljetin

8 - Campsa - Ravna

9 - Taliata - Donji Milanovac

10 - Hajducka Vodenica

11 - Transdierna - Tekija

12 - Sip

13 - Diana - Kladovo

14 - Donja Butorka

15 - Pontes - Kostol

\footnotetext{
${ }^{8}$ PROCOPIO DI CESAREA 1971
}

${ }^{9}$ PROCOPIO DI CESAREA 1544

\author{
16 - Rtkovo - Glamija \\ 17 - Milutinovac \\ 18 - Ljubicevac \\ 19 - Egeta
}

20 - Slatinska

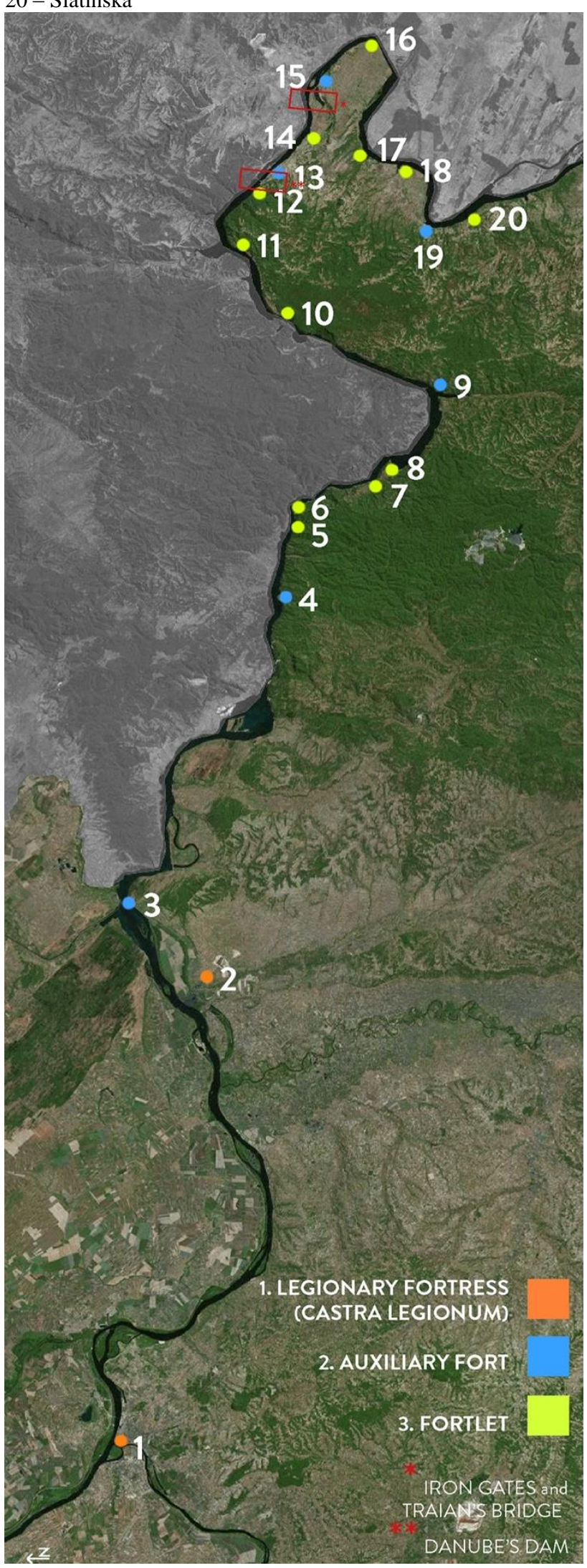


Figure 2. Archaeological sites belonging to the VI century mapped by the author.
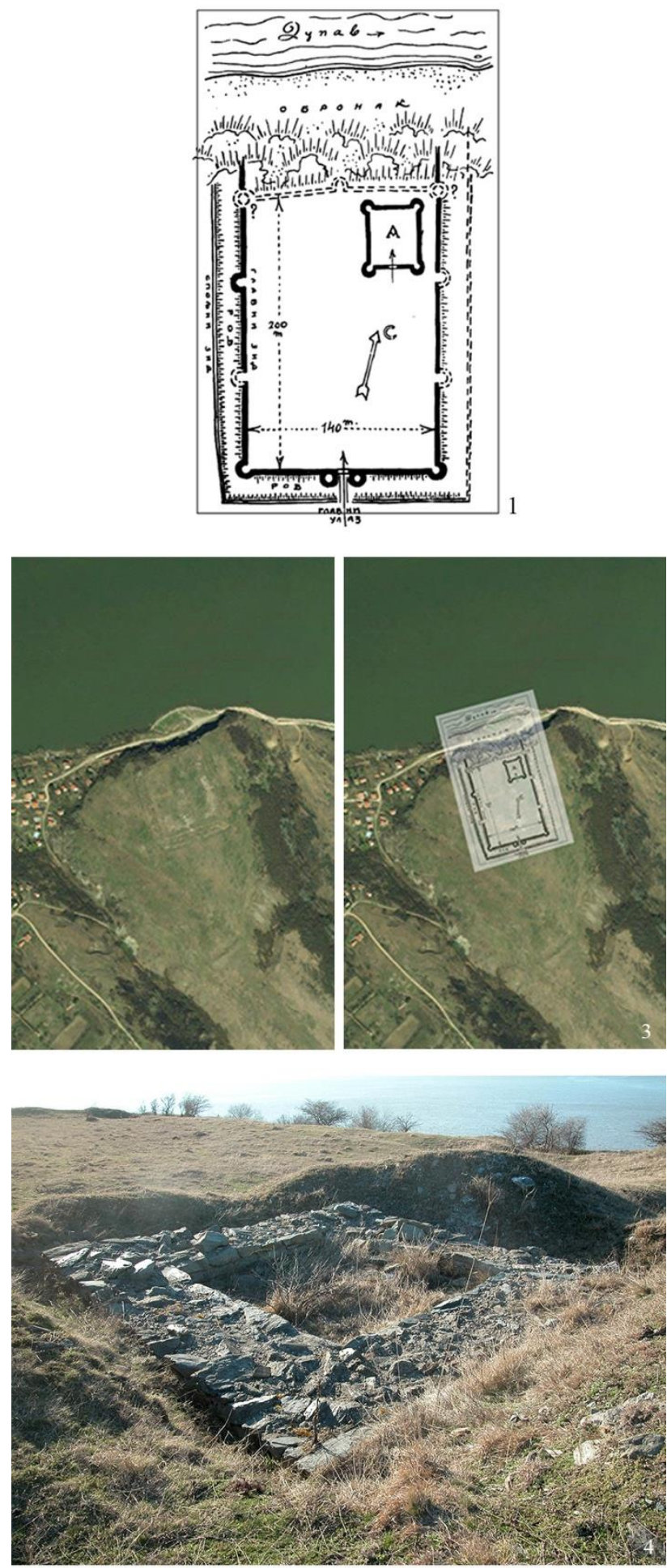

Figure 3. LEDERATA.

1: plan of the site (DIMITRIJEVIĆ, 1983-84); 2: image of the area from Bing Maps. 3: elaboration by the author, Dimitrijević plan on the aereal view of the site. 4: test on the archaeological site (limes2018.org/limes/ lederata)
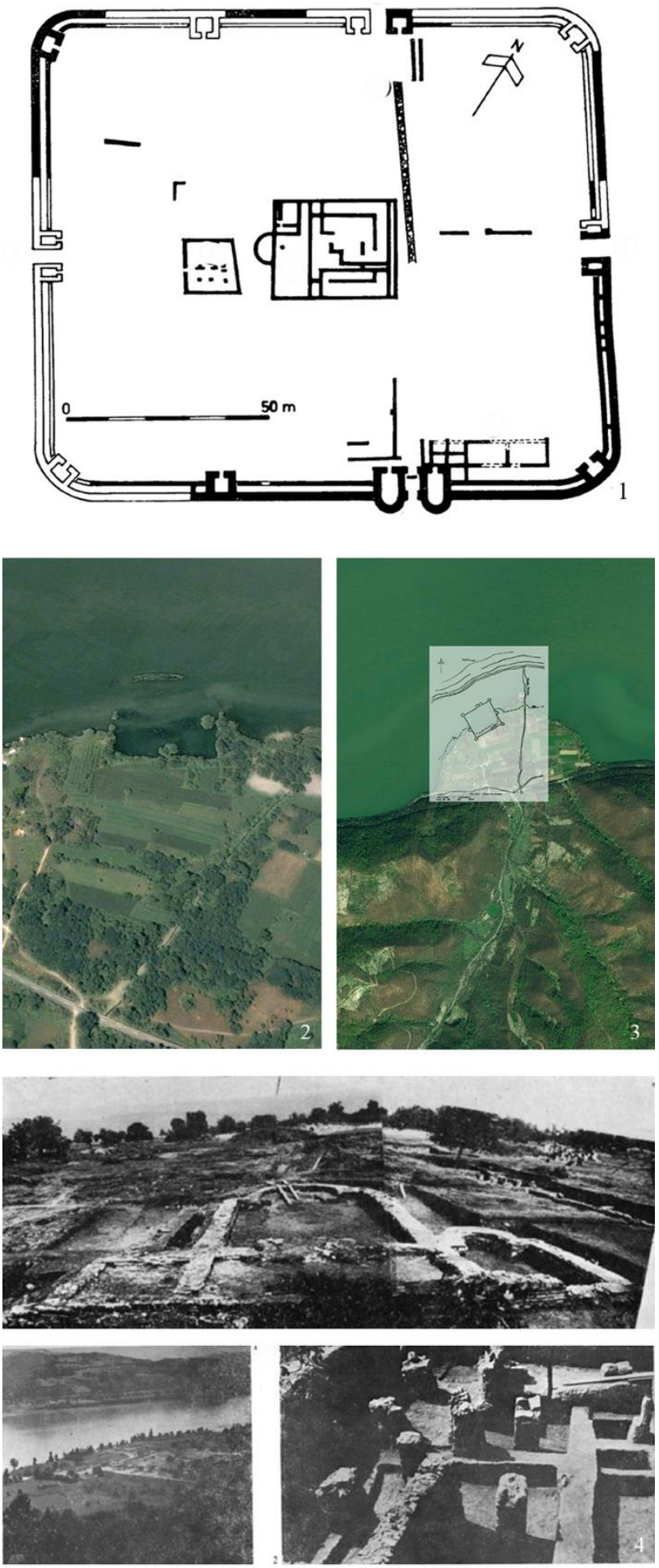

Figure 4. CASTRUM NOVAE

1: plan of the site (VASIĆ, 1983-84); 2: image of the area from Bing Maps. 3: elaboration by the author, Vasić plan on the aereal view of the site. 4: historical photos of the excavations

(VASIĆ, 1983-84). 

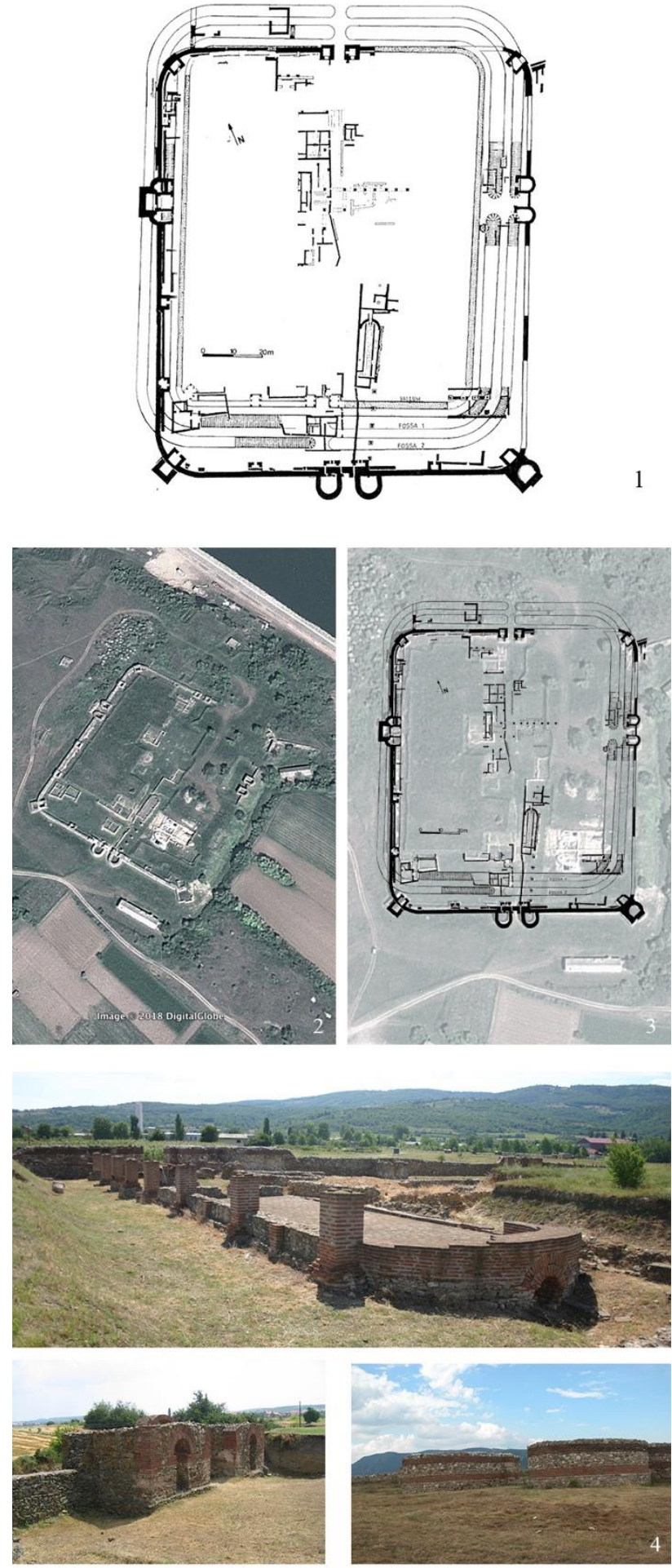

Figure 5. DIANA

1: plan of the site (KONDIC, 1983-84); 2: Image of the area from Bing Maps. 3: elaboration by the author, Kondic plan on the aereal view of the site. 4: photographies of the actual situation of the site (http://limes2018.org/limes/diana/).

\section{CONCLUSIONS}

With these three examples of case studies we tried to give an overview of the very irregular state of conservation of the archeological sites.

With the example of Lederata, we have a look on the case of an archaeological site that has not been excavated yet. As it is visible from the picture 3.3, on the left, coming from Bing Maps, the traces of the site are quite visible underground. During the ' 90 some excavation had been made as a test ${ }^{10}$.

In Castrum Novae, as visible from the pictures 4.4, the site has been totally excavated by archaeological campaigns during the 60 's. Thanks to that documents nowadays we could have a clear idea of the site, including the differences between the Roman settlement (white lines with black boundaries) and the Byzantine one (black lines), with the important presence of the Basilica at the centre of the settlement. Unfortunately, at it could be noticed by the figure 4.2, Castrum Novae may be considered as one of the most emblematic case of an archaeological site that was completely submerged by the water of the Danube river, after the construction of the dam.

Diana represents one of the better conserved sites, already excavated and restored during last few years. The case of this archaeological site has to be included in another category of our analysis. In a complex system of state and European grants, Diana is part of a network of sites called "Roman Emperors and Danube Wine Route", officially inscribed as one of the European Cultural Routes.

This project involves four different countries (Bulgaria, Croatia, Romania and Serbia) and "the Route links the archaeological sites with their individual (unique) histories that are monuments to the leadership of the Roman emperors in the introduction of Roman culture along the northern frontier of the Empire" 11 .

The aim of this research is to trying to give another input for the valorisation of those areas, putting in evidence how the network that the emperor Justinian I established during the VI century could be reinterpreted under a modern light.

\section{REFERENCES}

Bâjenaru, C., 2010. Minor Fortifications in the BalkanDanubian area from Diocletian to Justinia. Editura Mega, ClujNapoca, Bulgaria.

Cermanović-Kuzmanović A. Tekija (Transdierna), neka razmatranja (p. 337-343). In Starinar XXXIII-XXXIV, 19831984 Institute of Archaeology, Belgrade.

De Maffei F., 1988. Edifici di Giustiniano nell'ambito dell'Impero, Centro Italiano di Studi sull'Alto Medioevo, Spoleto.

Dimitrijević D. Sapaja, rimsko i srednjovekovno utvrdenje pa ostrvu kod Stare Palanke (p. 29-59). In Starinar XXXIIIXXXIV, 1983-1984 Institute of Archaeology, Belgrade.

Dujčev I., 1965. "Bisanzio e il mondo slavo", in Dujčev I., Medioevo bizantino-slavo. Edizioni di storia e letteratura, Roma.

Hösch E., 2006. Storia dei Balcani. Il Mulino, Bologna.

\footnotetext{
${ }^{10} \mathrm{http}: / /$ limes2018.org/limes/lederata/

$11 \mathrm{https}: / / \mathrm{www} . c 0 e . i n t / e n / w e b / c u l t u r a l-r o u t e s / t h e-r o m a n-e m p e r o r s-a n d-$ danube-wine-route
} 
Jęczmienowski E., 2012. The Fortifications of the Upper Moesian Limes. Topography, Forms, Garrison Sizes, in Światowit. In Annual of the Institute of Archaeology of the University of Warsaw), vol X (LI), fascicle A, Mediterranean and non-european archaeology. Institute of Archaeology, Warsaw.

Jovanović A. Hajdučka Vodenica kasnoantičko $i$ ranovizantijsko utvrdenje (p. 319-331). In Starinar XXXIIIXXXIV, 1983-1984 Institute of Archaeology, Belgrade.

Kondic V. Bosman, ranovizantijsko utvrdenje (p. 137-146). In Starinar XXXIII-XXXIV, 1983-1984 Institute of Archaeology, Belgrade.

Kondic V. Dijana - utvrdjenje 1 veka (p. 261-272). In Starinar XL-XLI, 1989-1990, Institute of Archaeology, Belgrade.

Kondic V. Ravna (Campsa) rimsko i ranovizantijsko utvrdenje (p. 233-253). In Starinar XXXIII-XXXIV, 1983-1984 Institute of Archaeology, Belgrade.

Korać M., Golubović S., Mrđić N., Jeremić G., Pop-Lazić S., 2014. Roman Limes in Serbia - Frontiers of the Roman Empire. Institute of Archeology, Belgrade.

Milosevic P. Sip, kasnoantičko utvrdenje (p. 357-362). In Starinar XXXIII-XXXIV, 1983-1984 Institute of Archaeology, Belgrade.

Obolensky D., 1971. The Byzantine Commonwealth. Praeger Publishers, Washington, New York.

Ostrogorsky G., 2014. Storia dell'Impero Bizantino. Einaudi Editore, Torino.

Popovic M. Svetinja, novi podaci o ranovizantijskom Viminacijumu (p. 1-37). In Starinar XXXVIII-1988. Institute of Archaeology, Belgrade.

Procopio di Cesarea, 1547. De Aedificiis. Michel Tramezino, Venezia. (translated in Italian, from the original version, in Greek, VI Cent., by Benedetto Egio da Spoleto).

Procopio di Cesarea, 1971. Procopius VII Buildings (De Aedificiis), translated in English from the original version in Greek by H. B. Dewing with the collaboration of Glanville Downey. Harvard University Press, Cambridge, Massachusetts.

Ronkey, S., 2002. Lo Stato bizantino. Einaudi, Torino.

Treadgold W., 2009. Storia di Bisanzio. Il Mulino, Bologna.

Vasić M. Čezava - castrum Novae (p.91-122). In Starinar XXXIII-XXXIV, 1983-1984 Institute of Archaeology, Belgrade.

Vasić M., 1990. Čezava - Castrum Novae. La stratigraphie, la chronologie et les phases architectoniques, in Limes 14 Carnuntum, (p. 897-911)

Zanini E., 1986. "Confine e frontiera: il limes danubiano nel VI secolo". In MILION studi e ricerche di arte.
Zotović LJ. Boljetin (Smorna), rimski i ranovizantijski logor (p.211-225). In Starinar XXXIII-XXXIV, 1983-1984 Institute of Archaeology, Belgrade. 